\title{
TRANSFORMATION PROCESSES OF THE CORPORATE DEVELOPMENT IN RUSSIA: CORPORATE SOCIAL RESPONSIBILITY ${ }^{1}$
}

Zh. S. Belyaeva

The financial and economic crisis made visible the level of readiness to changes in the different types of organizations throughout the world and Russia. The variation of social and economic programmes implemented by governmental and corporate sectors is widely seen; not all of them work positive for population, especially in the emerging markets countries. In the same time twenty years of the market economics in Russia, for instance, have definitely built a new social and economic system, but whether we have changed fundamentally in the

\footnotetext{
${ }^{1}$ Article is prepared by support of integration programme with scientists of Far East branch of Russian Academy of Sciences № 09-C-6-1004 «Regional socioeconomic policy as a tool of sustainable economic growth in terms of economic integration».
}

management techniques? The research generalizes some trends of the corporate development in Russia in the context of social responsibility and socio-economic transformation. The author attempts to define the Russia's place on the world map of corporate social responsibility.

Under conditions of world economy transformation, globalisation and gradual creation of a new model of global management the old values and the ideals based on the profit approach give way to priority socially important projects, and, hence, only socially-responsible companies can be successful participants of the world economy. Increase of the importance of nonmaterial factors of economic growth 
Approaches to the essence of the corporate social responsibility

\begin{tabular}{|l|l|l|}
\hline \multicolumn{1}{|c|}{ Type } & \multicolumn{1}{|c|}{ Theorists } & \multicolumn{1}{|c|}{ Essence of CSR } \\
\hline Liberal & T. Levitt (1958), M. Friedman (1970) & $\begin{array}{l}\text { The denial of economic benefits of CSR, compliance with legal and } \\
\text { business practices, liability rules and traditions, low level of support of } \\
\text { social projects }\end{array}$ \\
\hline Traditional & Business-environment reps & $\begin{array}{l}\text { Non-systematic support of social projects through sponsorship } \\
\text { and charity as a tribute to the market trend, social expenditures are } \\
\text { understood as equal to losses }\end{array}$ \\
\hline Social & $\begin{array}{l}\text { H. Bowen (1953), S. Sethi (1975), } \\
\text { D. Wood (1991) }\end{array}$ & $\begin{array}{l}\text { Internally - and client-oriented responsibilities (the production of } \\
\text { quality goods and services, paying taxes, creating jobs, decent wages) }\end{array}$ \\
\hline Strategic & $\begin{array}{l}\text { K. Davis (1960), R. W. Ackerman (1973), } \\
\text { E.Epstein (1987), Портер и Kреймеp } \\
\text { (2007) }\end{array}$ & $\begin{array}{l}\text { CSR - is an element of strategy, economic impact, which serves to } \\
\text { solve social, environmental problems, thrust into the external and } \\
\text { internal environment of the corporation. }\end{array}$ \\
\hline Integrated & $\begin{array}{l}\text { R. E. Freeman (1984), T.Donaldson, } \\
\text { L.Preston (1995), R.Steurer (2005), } \\
\text { O.Falk, S.Hiblich (2007) }\end{array}$ & $\begin{array}{l}\text { Orientation to the external and internal environment of the } \\
\text { corporation, counts on the interests of all stakeholders; CSR - is a part } \\
\text { of the corporate governance and has the economic effect }\end{array}$ \\
\hline
\end{tabular}

forces the companies to improve innovations and to introduce new technological achievements which put together the human, intellectual, social capital. All mentioned above sets the economic imperatives of socialisation of business.

The specifics of the capitalist development of western countries had been always a continuous and ongoing process that ended up with a difficult but balanced system of a regulation of mutual relations of the business and the society power in the sphere of social and economic development of the countries. Nowadays in different countries participation of business in the social problem-solving is strictly regulated in frames of the commercial, tax, labour, ecological legislation or carried out independently under the influence of specially established stimulus and privileges.

This process in Russia stands at the initial stages of development and occurs in the conditions of state dominant positions, extremely poor development of institutions of the civil society and oligarchic development of business. And rules of institutional cooperation, a role of different parties and a level of their participation in the social development only start to be formed [7].

The term "corporate development" itself has appeared in the Russian academic sources in the middle 90s', questions of efficiency of the given approach and corresponding tools are still under deep discussion in the local business environment. Social responsibility of the Russian business takes sources in aimless philanthropy of 90s', and in the western understanding has started its development only in 2001-2003.

According to some sources cultures, structures, and routines operating at multiple levels of jurisdiction become the carriers through which institutions impact firms [6]. Institutional theorists thus argue that corporate governance system will be determined largely by prevailing institutionalized norms in the organizational field and society.

The other theoretical perspective on corporate governance is a sociological perspective that builds on resource dependence theory - specifically, the influence of social networks on board formation and composition [5]. Fundamental to this perspective is the notion that a firm's actions are embedded in social networks, where embeddedness refers to the extent that actions are informed, influenced, and enabled by the network of accumulated stable and preferential social relations [3]. The final stakeholder theory of corporate governance system adopts a pluralistic approach to organizations [4]. Stakeholders have much more than just a passing interest in an organisation's outcomes. They also actively attempt to affect an organisation's behaviours in order to influence its direction so that it consistently meets the needs and priorities.

Comparative analysis of some approaches regarding maintenance, borders, display the forms of social responsibility of business allows to allocate five basic approaches: liberal, traditional, social, strategic and integrated (see tab. 1).

In sense of freedom of economic culture of stakeholders the situation has cyclic character. For example, position in corporate governance area in Russia up to 2004 correlates with a situation in America in the fifties. Thus, general meeting of the shareholders was purposely discharged from the company's activity, board of directors played passive role and the governance was duty of the head of the company.

Considering level of social and economic transformations in Russia 2000-2001 was the correct 
moment to begin an institutionalization of corporate development and social responsibility in Russia. Now the leading part in working out the standards of corporate governance system is played by regulating authorities that have begun an extensive educational campaign - introduction of economic culture of corporate governance system by means of specially developed principles of appropriate practice in Russia. After the last economic crisis in 2009-2010 the government power shared a big pie of the corporate regulations and management. So to say the Russian companies have again invisible, but tough hand.

Still in Russia the central player in general and corporate governance is a manager, who is inside of the business and builds a determined control system of business [2]. His commitments and overall objectives are to realize the potential of the enterprise. The main criterion of the efficiency is ROI. At the same time the manager builds relationships with the owner, proceeding from his interests, where the major motive is the growth of the business market value and return on the invested capital. The ROI is the basic criterion of an overall performance of business for the owner. The classic agency conflict of interests is the important element of the national business environment.

The organizational culture of a corporation of the technocratic type and the dominating style of management were based on decision-making control. A traditional approach considers an economic organization the «closed» system, its purposes and commitment are considered agreed and stable, as well as other conditions of activity, stable enough for a long time, and the sense of duty and an effective control have crucial importance in management techniques.

One of lines of the social and economic transformation in frames of corporate development in Russia is socially-responsible approach of business to corporate relations without dependence from obligatory and voluntary motives. Thus, the properly chosen factors concerning the dimension of the strategic choice lead to defining portfolio of categories shared by the members of corporate governance process. Moreover, we can find out which of the actual and potential interests we should fulfill, care about and protect. Strategies also reflect corporate values. An enterprise's core values, whether clearly announced or not, influence upon the selection of strategic goals and decisions on how the enterprise will negotiate and carry out its explicit and implicit contracts with stakeholders. Finally, the strategy identifies which stakeholders are important to the enterprise's success and why. Stakeholders may be important because they contribute to profitability, because corporate management and the board feel a sense of social responsibility to the stakeholder group, because the corporation is legally obliged to participate in that stakeholder group. The final major element also refers to the research of social relations - cultural context, which introduces to the model of corporate governance a process concerning shared values and possibility of their adoption into the whole enterprise. Some features of corporate development of a business environment of the Russian companies are systematised in table 2.

One of the basic problems of sharing CSR principles at the moment is the brevity of orientation of strategy of development of the companies, their dependence on stock market. W. Buffett marks possibility of negative consequences ориентированности on short-term investors for long-term development of the company [1].

The basic element of social and economic transformations is an embedding of the Russian economic culture in processes of world corporate development by integration of general values into the business environment of the company. Social responsibility is shown at different levels of social and economic systems. As it is already noted above, many researchers mark necessity of stronger contribution of Board of directors to development of corporate responsibility and building the corresponding corporate culture.

The corporate culture is helpful in understanding different symbols and activities; therefore it enables the stakeholders to find the most suitable solution. Moreover, using corporate structures, as a dimension in the description of corporate governance process can be useful in exploring values, which are required but may not exist at the time of research. Ethics control enables determining how the decisions are taken in respect with an increase of long-term value in an enterprise, and how they correspond to justice requirements regarding resource distribution.

Communication between leadership and socially responsible development of the company is the characteristic of the Russian model of social responsibility of business. High value of leadership in a control system routes in the Soviet understanding of «leader» as «the head», accordingly, leadership in realisation of corporate social responsibility can be considered as the technique of efficiency increase of the company. The strategy based on leadership demands a wide use of resources and the coordinated work of followers, which is the western characteristic of leadership.

The Corporations with leadership management type in Russia most successfully form the internal business processes, and also relations with an exter- 
Table 2

Stages of corporate development in the context of corporate governance (CG) and social responsibility trends (CSR)

\begin{tabular}{|c|c|c|c|c|}
\hline \multicolumn{2}{|c|}{\begin{tabular}{|c|}
$\begin{array}{c}\text { Players of corporate } \\
\text { development }\end{array}$ \\
\end{tabular}} & \multirow[b]{2}{*}{\begin{tabular}{l}
\multicolumn{1}{c}{$1991-1998$} \\
No control on corporations \\
and a passive management \\
role. A lot of shadow \\
acquisitions. A unique \\
economic culture routes in \\
90s. No strategic plans are \\
disclosed. Restructuring \\
might be a big surprise for the \\
shareholders
\end{tabular}} & \multirow[b]{2}{*}{\begin{tabular}{|l|}
\multicolumn{1}{|c|}{1 1999-2002 } \\
The wave of mergers and \\
acquisitions continues to \\
have a significant influence \\
on corporate governance \\
in Russia. Corporate \\
governance becomes the \\
center of public interest, \\
the code of corporate \\
conduct is worked out
\end{tabular}} & \multirow[b]{2}{*}{\begin{tabular}{|l|}
\multicolumn{1}{|c|}{$2003-$ present } \\
Russian model of corporate governance \\
starts to have specifics if compared to the \\
Anglo-American, German or Japanese. The \\
Regulators start an educational campaign- \\
a culture of good corporate governance \\
through a specially developed principles \\
of good corporate governance practices in \\
Russia
\end{tabular}} \\
\hline 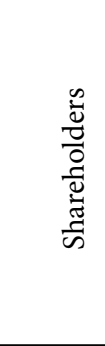 & CG & & & \\
\hline \multirow[t]{2}{*}{ 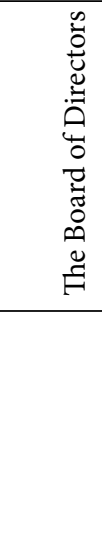 } & CG & $\begin{array}{l}\text { Passive role, the minimum } \\
\text { number of independent } \\
\text { directors as outsiders. } \\
\text { Directors lobby the interests of } \\
\text { those groups of shareholders } \\
\text { who voted for them }\end{array}$ & $\begin{array}{l}\text { The old leaders come } \\
\text { to power in the newly } \\
\text { established companies. The } \\
\text { practice of combining two } \\
\text { posts as the CEO and its } \\
\text { Boards' chairman remains }\end{array}$ & $\begin{array}{l}\text { «Increasing the corporate value», the } \\
\text { role of the Board of Directors increases } \\
\text { and the recognition of the importance of } \\
\text { the Board. The presence of independent } \\
\text { directors on the board of directors has } \\
\text { signs of progressive companies. Leaders } \\
\text { of corporations - professional managers } \\
\text { instead of the former government leaders }\end{array}$ \\
\hline & CSR & $\begin{array}{l}\text { The orientation of business to } \\
\text { social needs of the State (often } \\
\text { compulsory) }\end{array}$ & $\begin{array}{l}\text { Point support for social } \\
\text { projects, work towards } \\
\text { national goals in social } \\
\text { policy, restructuring of } \\
\text { CSR support structure at } \\
\text { the corporate level }\end{array}$ & $\begin{array}{l}\text { Strategically verified statement of priorities } \\
\text { in the corporate social policy, functional } \\
\text { committees on social strategy. CSR is still } \\
\text { mainly seen as a personnel care and non- } \\
\text { profit charity to PR the company }\end{array}$ \\
\hline \multirow{2}{*}{ 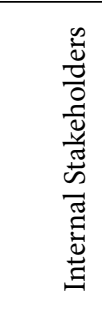 } & CG & $\begin{array}{l}\text { Control in the hands of } \\
\text { the executive directors, top } \\
\text { management has enhanced } \\
\text { powers }\end{array}$ & $\begin{array}{l}\text { The management stays the } \\
\text { central decision part of } \\
\text { company }\end{array}$ & $\begin{array}{l}\text { Actualized social policy issues with respect } \\
\text { to employees (training and education } \\
\text { and incentives, health care and improved } \\
\text { working conditions, voluntary health } \\
\text { insurance, corporate pension funds, etc.) }\end{array}$ \\
\hline & CSR & $\begin{array}{l}\text { Caring of the employees and } \\
\text { their families at default basic } \\
\text { elements (taxes, workday, etc.) }\end{array}$ & $\begin{array}{l}\text { Increase of the social } \\
\text { package quality. }\end{array}$ & $\begin{array}{l}\text { Social support to employees and their } \\
\text { families, work on the formation and } \\
\text { implementation of corporate culture }\end{array}$ \\
\hline \multirow{2}{*}{ 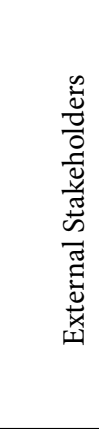 } & CG & $\begin{array}{l}\text { Institutional norms are not } \\
\text { developed, legislation and } \\
\text { regulatory bodies do not have } \\
\text { the appropriate tools }\end{array}$ & $\begin{array}{l}\text { Appearance of the class } \\
\text { of institutional investors, } \\
\text { a formalized structure of } \\
\text { regulation of corporate } \\
\text { governance }\end{array}$ & $\begin{array}{l}\text { The state actively involved in the } \\
\text { development of the corporate sector, it is } \\
\text { often called "the invisible hand" }\end{array}$ \\
\hline & CSR & $\begin{array}{l}\text { Support for government social } \\
\text { agencies (particularly from the } \\
\text { impact of enterprise) }\end{array}$ & $\begin{array}{l}\text { Support the general thrust } \\
\text { of unrelated one-time } \\
\text { projects, social marketing. }\end{array}$ & $\begin{array}{l}\text { Competitive selection of programs for } \\
\text { social investment, management of the } \\
\text { company image using CSR as a tool. The } \\
\text { appearance of the spectrum of tools to } \\
\text { deliver information about corporate social } \\
\text { responsibility to stakeholders. }\end{array}$ \\
\hline
\end{tabular}

nal business environment; for this reason they can be considered as socially responsible. The phenomenon of leadership in a corporation and in frames of the corporate relations system is the mechanism that uses innovative approaches through potential of the «higher» degree in inventing the organizational, social and economic superiority over competitors. It is the main result of transformation of corporate social development.

Russia has a possibility to take lessons from foreign experience. So achievement of the new social contract between the state, business community and a civil society, the problem fixed in the European social model, is actual for us as well. Certainly, each country has the features of unique development, tradition, national interests. But in the context of globalisation all members of world economy need to solve similar problems related to the interests of an individual, protection of his advantage, living conditions and work, social protection. World models of social responsibility of business form vectors of social architecture of the Russian business and the variants of its development that match to the calls of the XXI ${ }^{\text {st }}$ century. 
Comparative Characteristics of the Common Models of Social Responsibility

\begin{tabular}{|c|c|c|c|}
\hline \multicolumn{4}{|c|}{ The grouped models of corporate social responsibility in the world economy } \\
\hline \multicolumn{2}{|c|}{ European } & \multirow{2}{*}{$\begin{array}{c}\text { American } \\
\begin{array}{c}\text { USA, Canada, Latin America, } \\
\text { Anglophone Africa }\end{array}\end{array}$} & \multirow{2}{*}{$\begin{array}{c}\text { Asian } \\
\text { Japan, South Korea, China, } \\
\text { Malaysia, Thailand }\end{array}$} \\
\hline $\begin{array}{l}\text { Belgium, the Netherlands, } \\
\text { Sweden }\end{array}$ & $\begin{array}{l}\text { Austria, Germany, France, } \\
\text { and partially Great Britain }\end{array}$ & & \\
\hline $\begin{array}{l}\text { Active participation of the } \\
\text { state in regulating social } \\
\text { and labour relations, as well } \\
\text { as what is happening at the } \\
\text { country level, industry, indi- } \\
\text { vidual companies. }\end{array}$ & $\begin{array}{l}\text { State intervenes in social } \\
\text { and labour relations, but the } \\
\text { employers and trade unions } \\
\text { retain autonomous. This is the } \\
\text { inclusion of social activities in } \\
\text { the overall strategy of creating } \\
\text { added value. }\end{array}$ & $\begin{array}{l}\text { The state role consists of ap- } \\
\text { proving the corresponding } \\
\text { legislative and statutory acts, } \\
\text { recommendations and require- } \\
\text { ments. Regulation of sociola- } \\
\text { bour relations at the level of an } \\
\text { enterprise and in much smaller } \\
\text { degree at a regional level. } \\
\text { Investor considers charity as } \\
\text { a sign of social stability of the } \\
\text { company that with other things } \\
\text { attracts more investment. }\end{array}$ & $\begin{array}{l}\text { The state is actively involved, } \\
\text { sometimes leads CSR, and } \\
\text { business provides shelter, } \\
\text { encourages family dynasties, } \\
\text { carries out training at the } \\
\text { expense of corporate respon- } \\
\text { sibility for social programs } \\
\text { in specific enterprises, and } \\
\text { contained the entire social } \\
\text { infrastructure. }\end{array}$ \\
\hline \multicolumn{2}{|c|}{$\begin{array}{l}\text { The integrated tripple approach (economic, ecological and } \\
\text { social) }\end{array}$} & Economic Vector & Social Vector of partnership \\
\hline \multicolumn{4}{|c|}{ THE RUSSIAN MODEL } \\
\hline \multicolumn{2}{|c|}{ Adopted (shared) features } & \multicolumn{2}{|c|}{ Unique features } \\
\hline \multicolumn{2}{|c|}{$\begin{array}{l}\text { Active participation of the state in advancement of social re- } \\
\text { sponsibility, regulation of sociolabour relations. } \\
\text { The private-public partnership in CSR } \\
\text { The enterprises with the state participation provide all social } \\
\text { infrastructures. }\end{array}$} & \multicolumn{2}{|c|}{$\begin{array}{l}\text { Compulsory character of social responsibility of the large } \\
\text { companies } \\
\text { The Essence of the social responsibility of business at each } \\
\text { group of companies it is original and different (both with ex- } \\
\text { ternal, and with internal social policy of the company). } \\
\text { Non-systematic hyper-charity } \\
\text { The Social reports might not correspond to the corporate val- } \\
\text { ues of the company and might be declared only on a paper. }\end{array}$} \\
\hline
\end{tabular}

The analysis of world practice allows allocating some types of corporate social responsibility that vary depending on orientation vector of programs and state participation. In our opinion, all these features have made essential impact on formation of the Russian model of corporate responsibility. Although as well as concerning national model of corporate governance, there are still many academic disputes.

The institutional contour of built Russian model of social responsibility should consider essential types of ideological, economic, political and the public work, directed on harmonisation of balance of interests of all stakeholders. The borrowed and unique lines of the Russian model start to take a steady form. Some aspects of features of world models of social responsibility are reflected in table 3 .

The dynamics of the current stage of corporate development in a context of increase of corporate social responsibility gives a good possibility to the Russian business community to raise the level of economic culture and to integrate national corporations into the world map of social responsibility. It will allow generating a positive investment and corporate climate in the Russian business environment in frames of world corporate development model.

\section{References}

1. Бафбет У. Эссе об инвестициях, корпоративных финансах и управлении компаниями. М.: Альпина Бизнес Букс, Альпина Паблишерз, 2009. 272 с.

2. Иванова В. Особенности формирования моделей корпоративной социальной ответственности в зарубежных странах и России//Человек и труд, 10/2009. url: http:// www.chelt.ru/2009/10-09/ivanova_10-09.html (дата обращения: 24.11.2010)

3. Granovetter, M. Economic action and social structure: A theory of embeddedness. American Journal of Sociology, 1985. № 91. P. 481-510.

4. Freeman, R. E. Strategic management: A stakeholder approach. B.: Pitman Publishers, 1984. 276 p.

5. Pfeffer J. New Directions for Organizational Theory. N. Y.: Oxford University Press, 1997.264 p.

6. Scott, W. R. Institutions and organizations: Foundations for organizational science. Sage Publications, Inc, 2nd ed., 2000. $277 \mathrm{p}$.

7. Russia and Slovakia: modern tendencies of demographic and socioeconomic processes / General Editor: Academician Tatarkin A. I. Ekaterinburg: Institute of Economics, Russian Academy of Sciences, Ural Branch, 2009. 218 pp.

UDC: $339.926:$ 332.012.2

keywords: corporate development, corporate social responsibility, managerial leadership 